\title{
Anti-Inflammatory Activity of the Fruit Extract of Benincasa hispida
}

\author{
Deepak Kadam and Smita Lele*
}

\author{
Food Engineering and Technology Department, Institute of Chemical Technology, N. P. Marg, Matunga, \\ Mumbai 400019, India
}

\begin{abstract}
Benincasa hispida (Ash gourd, family: Cucurbitaceae) is well known for its medicinal property. In the Ayurvedic system, it is used as a rejuvenating agent and in the treatment of nervous disorders. Methanolic and petroleum fruit extracts was subjected to evaluation of phytochemicals and acute oral toxicity study. Further, Antiinflammatory activity was performed using human red blood cell (HRBC) membrane stabilization assay and carrageenan induced paw edema in rat. Oral administration of methanolic extract of concentration $(350 \mathrm{mg} / \mathrm{kg})$ significantly reduced the paw edema $(P<0.05)$ in a dose dependent manner as compared to carrageenan induced rats.
\end{abstract}

Keywords: Benincasa hispida, Phytochemicals, Anti-inflammatory, HRBC membrane stabilization, Carrageenan.

\section{INTRODUCTION}

Nature has provided many compounds of significant medicinal application that play an important \& often dominant role in the maintenance of human health. Natural plant products such as herbs, fruits and vegetables have became more popular in recent years due to public awareness and developing significance in the pharmacological evaluation. Now days, Indian traditional Ayurvedic systems of medicine has increasing interest among consumers and the scientific community prefer to control their health with the help of natural plant medicines [1]. Plant medicines has wide variety of free radical scavenging molecules, such as phenolic compounds, amines, vitamins, terpenoids, carotenoids [2] and some endogenous metabolites, which are rich in antioxidant activity and antiinflammatory activity [3].

Inflammation is a complex part of the body's immune response to a native substance which produces excessive amount of free radical causing lipid peroxidation resulting in membrane destruction followed by production of mediator and chemotactic factor [4]. It is also correlated with the different disease such as rheumatism, encephalitis, fibrosis, cancer [5], heart problem etc. NSAIDs anti-Anti-inflammatory drugs are most widely used for the treatment of inflammation of various kinds, but can cause many adverse effects. Therefore there is a need to emphasize on research for discovery of antiinflammatory agent from natural sources. Herbal extracts and treatments are found to be safer alternatives so extensive research can be done for potential anti inflammatory activity.

${ }^{*}$ Address correspondence to this author at the Food Engineering and Technology Department, Institute of Chemical Technology, N. P. Marg, Matunga, Mumbai 400019, India; Tel: +9122 3361 1111; Fax: +9122 241456 14; E-mail: dr.smita.lele@gmail.com
Benincasa hispida also known as Ash gourd belongs to the family of Cucurbitaceae. They are of great interest due to their wide range of biological activity. It is considered as a good source of valuable nutrients including organic acids, natural sugars, amino acids, vitamins and mineral elements. The fruit possesses anti-ulcer [6], anti-angiogenic [7], antihistamines [8], anti-inflammatory [9] antioxidant and angiotensin-converting enzyme(ACE) inhibitors [10], anorectic [11], and hypoglycemia [12] properties. The large fraction that are responsible for the above mentioned activities in ash gourd fruits are flavonoids [13], sacchrides, triterpenoids, proteins, carotene, glycosides, vitamins, minerals, $\beta$-sitosterin, uronic acids, lupeol and sterols [14].

In this present work, an attempt has been made to investigate the phytochemicals and anti-inflammatory activity of methanolic and petroleum ether extracts of Benincasa hispida fruit by Human red blood cell (HRBC) membrane stabilization and carrageenan induced paw edema in rat methods.

\section{MATERIALS AND METHODS}

\subsection{Preparation of Extract}

Fresh fruit, Benincasa hispida was collected from the Matunga market, Mumbai, INDIA. The fruit was chopped and seeds were separated. Further, fruit were air dried, powdered and passed through the 60 mesh size sieve. It was then sequentially extracted using hot Soxhlet method with solvents like petroleum ether, methanol, ethyl acetate and water, each used in their increasing order of polarity. The extracts were dried under reduced pressure at temperature $42 \stackrel{\circ}{ } \mathrm{C}$. The crude extract was vacuumed dried and stored at low temperature. 


\subsection{Chemical and Instrument}

All chemicals used in the experiment were of analytical grade (HiMedia, Mumbai Chapter). Carrageenan was procured from Sigma Chemicals. Reference standard acetylsalicylic acid (ASA; Ecosprin) was obtained from USV Ltd (Mumbai, India). Detection for the in vitro assay was performed by UV Visible spectrophotometer.

\subsection{Phytochemical Evaluation}

Standard phytochemicals screening tests were performed to identify the different constituents present in methanol and petroleum ether extracts of fruit [15].

\subsection{Animal}

Healthy Albino Wistar rat $(150-250 \mathrm{gm})$ and Albino Swiss mice (18-22gm) of female sex were procured from the Haffkine Biopharmaceuticals (Mumbai, India). They were housed at the Animal Testing Centre (CPCSEA/315). Procedure for animal maintenance and experimentation was carried out as per guidelines of CPCSEA, Government of India. Animals were given free access to standard laboratory food and water. Animals were maintained in polypropylene cages. Standard conditions of temperature $\left(22+5^{\circ} \mathrm{C}\right)$ and humidity $(55+15 \%)$ were maintained with a $12 \mathrm{~h}$ lightdark cycles. All animals were acclimatized for 1 week before experimental procedures were carried out. The Experimental study procedure was approved by the Institutional Animal Ethics Committee.

\subsection{Acute Toxicity Study}

Acute toxicity study was performed as per OECD guidelines 420 .

\subsection{In-Vitro Anti-Inflammatory Activity}

The HRBC membrane stabilization assay was used for the estimation of in vitro anti-inflammatory activity according to TK Mohamed Saleem et al. (2011) with some modification. Whole human blood was freshly collected and mixed with equal volume of sterilize Alsever solution. The sample was centrifuged at 3000 rpm for 10 min. Further supernatant was separated and packed cells (sediments) were washed with isosaline for three consecutive times. Quantification of red blood cell was determined and redeem with isosaline $(10 \%$ $\mathrm{v} / \mathrm{v})$. The principle behind this is; the hypotonicity triggers membrane lysis which in-turn stabilises human RBC membrane. Different concentration of fruit extract, reference sample and control samples were mixed with
(1 $\mathrm{ml})$ phosphate buffer, $(2 \mathrm{ml})$ hyposaline and $(0.5 \mathrm{ml})$ HRBC suspension. Samples were further incubated at $37{ }^{\circ} \mathrm{C}$ for $30 \mathrm{~min}$ and centrifuged. The haemoglobin quantity in the sample was estimated by the spectrophotometric analytical method at $560 \mathrm{~nm}$. The percent hemolysis was evaluated by considering the hemolysis generated in the control as $100 \%$.

$\%$ Protection $=100-[(\mathrm{OD}$ of Test sample $/ \mathrm{OD}$ of Control) X 100

\subsection{In Vivo Anti-Inflammatory Activity}

Paw oedema was induced on each rat by transfusing $0.1 \mathrm{ml}$ of $1 \% \mathrm{w} / \mathrm{v}$ carrageenan on physiological saline. The methanolic and petroleum ether extract at different concentration were administrated orally for 60 minutes after carrageenan administration. Paw volume was measured immediately $(0 \mathrm{~h})$ and thereafter measured at $1 \mathrm{~h}$ intervals for $4 \mathrm{~h}$ by method based on the Archimedes' principle of buoyancy and hydrostatic pressure [16]. The percentage inhibition of paw volume was compared between control and both the extract. Acetylsalicylic acid $(300 \mathrm{mg} / \mathrm{kg}$ ) was used as the standard.

\subsection{Statistical Analysis}

Statistical analysis and interpretation was done using one way analysis of variance followed by Dunnets test. $P<0.05$ were considered as significant.

\section{RESULTS}

\subsection{Phytochemical Evaluation}

The phytochemicals characteristics of petroleum ether and methanolic extract of the edible part of the fruit were tabulated in Table 1. Analysis of the edible part of fruit extracts revealed the presence of phytochemical such as phenols, tannins, flavonoids, saponins, glycosides, steroids, terpenoids, and alkaloids.

\subsection{Acute Toxicity Studies}

The concentration of methanolic and petroleum fruit extract of Benincasa hispida up to $2000 \mathrm{mg} / \mathrm{kg}$ body weight did not show any sign of toxicity and hence it was considered to be safe.

\subsection{In Vitro Anti-Inflammatory Activity}

To measure the anti inflammatory activity, the protection of membrane stabilization of RBC was 
Table 1: Phytochemical Constituents of Petroleum Ether and Methanolic Extract of Benincasa hispida Fruit

\begin{tabular}{|c|c|c|}
\hline \multirow{2}{*}{ Phytochemical } & \multicolumn{2}{|c|}{ Benincasa hispida fruit } \\
\cline { 2 - 3 } & Petroleum ether extract & Methanol extract \\
\hline \hline Alkaloids & $+\mathrm{ve}$ & $+\mathrm{ve}$ \\
\hline Flavonoid & $+\mathrm{ve}$ & $+\mathrm{ve}$ \\
\hline Glycoside & $-\mathrm{ve}$ & $-\mathrm{ve}$ \\
\hline Saponine & $-\mathrm{ve}$ & $+\mathrm{ve}$ \\
\hline Phytosteroid & $+\mathrm{ve}$ & $+\mathrm{ve}$ \\
\hline Polyphenol & $+\mathrm{ve}$ & $+\mathrm{ve}$ \\
\hline Triterpenoid & $+\mathrm{ve}$ & \\
\hline
\end{tabular}

Note: (+ve) Indicates presence of phytoconstituent, (-ve) Indicate absence of phytoconstituent.

considered. The components present in the extract possibly have maintained the tonicity and may have balanced the membrane which prevented the inhibition of HRBC membrane lysis due to reduction of hypotonicity. The percent of membrane stabilization for methanolic and petroleum ether extracts were studied at different concentration $(150,250,350 \mathrm{mg} / \mathrm{ml}$ ). The percent protection of methanolic extract at concentration $350 \mathrm{mg} / \mathrm{ml}$ for membrane stabilization was found to be higher. The results were tabulated in Table 2.

\subsection{In Vivo Anti-Inflammatory Activity}

The methanolic and petroleum extract of Benincasa hispida fruit at different concentration showed significant reduction in the paw volume of rat. The methanolic extract at a concentration of $350 \mathrm{mg} / \mathrm{ml}$ showed significant activity in comparison to the

Table 2: In-Vitro Anti-Inflammatory Activity of Fruit Extract of Benincasa hispida

\begin{tabular}{|c|c|c|}
\hline Sr. No & Extract type(mg/ml) & Percentage of protection \\
\hline \hline 1 & Methanolic-150 & 12.16 \\
\hline 2 & Methanolic-250 & 15.74 \\
\hline 3 & Methanolic-350 & 17.31 \\
\hline 4 & Petroleum ether- 150 & 7.41 \\
\hline 5 & Petroleum ether- 250 & 10.04 \\
\hline 6 & Petroleum ether- 350 & 14.23 \\
\hline 7 & Ecosprin tablet(acetylsalicylic acid) -25 & 24.57 \\
\hline
\end{tabular}

Table 3: In-Vivo Anti-Inflammatory Activity of Fruit Extract by Benincasa hispida, Carrageenan-Induced Rat Paw Edema

\begin{tabular}{|c|c|c|c|c|c|c|c|}
\hline Group & $\begin{array}{c}\text { Treatment } \\
\text { Design }\end{array}$ & Dose $(\mathbf{m g} / \mathbf{k g})$ & \multicolumn{4}{|c|}{ Carrageenan induced oedma (volume in $\mathbf{m l})$} \\
\cline { 4 - 7 } & & & $\mathbf{0} \mathbf{~ m i n}$ & $\mathbf{6 0} \mathbf{~ m i n}$ & $\mathbf{1 2 0} \mathbf{~ m i n}$ & $\mathbf{1 8 0 m i n}$ & $\mathbf{2 4 0} \mathbf{m i n}$ \\
\hline \hline i & $\begin{array}{c}\text { Induced control } \\
(1 \% \text { carageenan in saline) }\end{array}$ & & $1.05 \pm 0.08$ & $1.26 \pm 0.09$ & $1.45 \pm 0.08$ & $1.53 \pm 0.13$ & $1.75 \pm 0.14$ \\
\hline ii & $\begin{array}{c}\text { Ecosprin tablet } \\
\text { (acetylsalicylic acid) }\end{array}$ & 300 & $0.98 \pm 0.07$ & $1.11 \pm 0.17$ & $1.25 \pm 0.11^{*}$ & $1.10 \pm 0.10^{*}$ & $0.96 \pm 0.15^{*}$ \\
\hline iii & Methanolic extract & 250 & $1.06 \pm 0.12^{\mathrm{a}}$ & $1.21 \pm 0.08$ & $1.35 \pm 0.14$ & $1.28 \pm 0.12^{*}$ & $1.23 \pm 0.05^{\mathrm{a} *}$ \\
\hline iv & Methanolic extract & 350 & $1.03 \pm 0.46^{\mathrm{a}}$ & $1.13 \pm 0.11$ & $1.23 \pm 0.11^{*}$ & $1.21 \pm 0.10^{*}$ & $1.18 \pm 0.08^{*}$ \\
\hline v & Petroleum ether extract & 250 & $0.97 \pm 0.13$ & $1.11 \pm 0.10$ & $1.35 \pm 0.11$ & $1.43 \pm 0.08^{\mathrm{a}}$ & $1.41 \pm 0.12^{\mathrm{a} *}$ \\
\hline vi & Petroleum ether extract & 350 & $1.00 \pm 0.10$ & $1.18 \pm 0.10$ & $1.38 \pm 0.14$ & $1.38 \pm 0.08^{\mathrm{a}}$ & $1.28 \pm 0.08^{\mathrm{a} *}$ \\
\hline
\end{tabular}

Values are expressed in mean \pm SEM $(n=6) ;{ }^{*}: p<0.05$ with control; a: $p<0.05$ with standard. 
reference standard Ecosprin. The results are presented in Table 3.

\section{DISCUSSION}

Inflammation is a response of living tissue towards injury, infection or irritation. During the inflammation process the activated neutrophils such as bactericidal enzymes and protease are released by lysosome which may cause various disorders. The activated neutrophils released enzymes can cause the tissue injury which may damage the macromolecules and lipid peroxidation of membranes that are assumed to be responsible for globally prevalence disease, such as atherosclerosis, rheumatoid arthritis and asthma. Phytochemical evaluation of petroleum extract and methanolic extract of Benincasa hispida revealed the presence of alkaloid, flavonoid, glycoside, phytosteroid, polyphenol and tryterpenoid.

In the present study, in-vitro anti-inflammatory assay was studied based on HRBC membrane stabilization method. As the erythrocyte membrane possesses a similar structure with the lysosomal membrane, [17] therefore the stability suggests that the extract may have maintained lysosomal membranes. The application of extract indicated the stability of lysosomal membrane that is important in restricting inflammatory response by inhibiting the release of lysosomal enzymes. The result indicates that fruit extract of Benincasa hispida has significant in-vitro anti-inflammatory property.

The carrageenan-induced inflammation is practical and significant model for the evaluation of in-vivo antiinflammatory effect [17]. The expansion of carrageenan induced edema in the paw of rat is represented by a biphasic curve [18]. The first phase involves the release of histamine, 5-HT and kinins [19] along with platelet activating factor and arachidonic acid metabolites [20]. Edema is a result of the liberation of Prostaglandins (PGs) as they are the most significant factor in the advancement of the second phase of the reaction that is estimated at around $3 \mathrm{~h}$ times [21]. Fruit extract of Benincasa hispida showed a significant antiinflammatory effect and it may be due to the inhibition of any inflammatory mediators by the glycoside or steroid [18]. Flavonoids, tritrepenoids and polyphenols are active components widely found in the fruit extracts which may be responsible for anti-inflammatory activity $[2,13]$. The present work reveals that the methanolic fruit extract of Benincasa hispida is a potential therapeutic agent for the treatment of inflammation.

\section{CONFLICT OF INTEREST STATEMENT}

We declare that we have no conflict of interest.

\section{ACKNOWLEDGEMENT}

The authors are thankful to the management, director and faculties of Institute of chemical technology for rendering the necessary requirements in this work.

\section{REFERENCE}

[1] Thaipong K, Boonprakob U, Crosby K, Cisneros-Zevallos L, Byrne DH. Comparison of ABTS, DPPH, FRAP, and ORAC assays for estimating antioxidant activity from guava fruits extracts. J Food Compos Anal 2006; 19: 669-675.

[2] Volluri SS, Rao BS, Chippada SC, Vangalapati M. In-Vitro Anti-Arthritic Activity of Methanolic Extract of Bacopa Monnier. IJCEPR 2011; 2(2): 156-159.

[3] Rabbani M, Sajjadi SE, Zarei HR. Anxiolytic effects of Stachys lavandulifolia Vahl on the elevated plus maze model of anxiety in mice. J Ethnopharmacology 2003; 89: 271-276. http://dx.doi.org/10.1016/j.jep.2003.09.008

[4] Lewis DA. Anti-inflammatory drugs from plant and marine sources 1989; p. 135.

[5] Goodwin JS, Brodwick M, Diet, Ageing and Cancer. Clin Geriatr Med 1995; 11: 577-589.

[6] Grover JK, Adiga G, Vats V, Rathi SS. Extracts of Benincasa hispida prevent development of experimental ulcers. J Ethnopharmacol 2001; 78(2-3): 159-64. http://dx.doi.org/10.1016/S0378-8741(01)00334-8

[7] Lee $\mathrm{KH}$, Choi HR, Kim CH. Anti-angiogenic effect of the seed extract of Benincasa Cogniaux. J Ethnopharmacol 2005; 97(3): 509-13.

http://dx.doi.org/10.1016/j.jep.2004.12.008

[8] Kumar AD, Ramu P. Effects of methanolic extract of Benincasa hispida against histamine and acetylcoline induced bronchospam in guinea pigs. Indian $\mathrm{J}$ Pharmacol 2004; 34: 365-366

[9] Chandra BS, Umamageshwari S. Studies on antiinflammatory activity of fruit rind extract of Benincasa hispida Cogn. India Drugs 2002; 39: 9-13.

[10] Huang HY, Huang JJ, Tso TK, Tsai YC, Chang CK Antioxidant and angiotensin- converting enzyme inhibition capacities of various parts of Benincasa hispida (wax gourd). Nahrng 2004; 48(3): 230-3. http://dx.doi.org/10.1002/food.200300428

[11] Kumar A, Vimalavathini R. Possible anorectic effect of methanol extract of Benincasa hispida (Thunb) Cogn, fruit. Indian J Pharmacol 2004; 36: 348-350.

[12] Dong MY, Lumz, Yin QH, Feng WM, Xu JX, Xu WM. Study of Benincasa hispida contents effective for protection of kidney. Jiangsu J Agric Sci 1995; 1: 46-55.

[13] Pawlowska AM, Oleszek W, Braca A. Quali-quantitative analyses of flavonoids of Morus nigra $\mathrm{L}$. and Morus alba $\mathrm{L}$. (Moraceae) fruits. J Agric Food Chem 2008; 56(9): 33773380 .

http://dx.doi.org/10.1021/jf703709r

[14] Rosa MD, Giround JP, Willoghby DA. Studies of the acute inflammatory response induced in rats in different sites by Carrageenan and turpentine. J Pathol 1971; 104: 15-29. http://dx.doi.org/10.1002/path.1711040103

[15] Harborne JB. Phytochemical methods guide to modern Technique of Plant Analysis, $3^{\text {rd }}$ ed. Chapman and Hall, London 1998; 1: p. 135. 
[16] Shejawal N, Menon S, Shailajan S. A simple, sensitive and accurate method for rat paw volume measurement for rat paw volume measurement and its expediency in principle animal studies. Human Exper Toxicol 2013; 33(2): 123-129. http://dx.doi.org/10.1177/0960327113482594

[17] Mohamed Saleem TK, Azeem AK, Dilip C, Sankar C, Prasanth NV, Duraisami R. Anti-inflammatory activity of the leaf extacts of Gendarussa vulgaris Nees. Asian Pacific J Trop Biomed 1911; 147-149.

[18] Rupasinghe VHP, Clegg S. Total antioxidant capacity, total phenolic content, mineral elements, and histamine concentrations in wines of different fruit sources. J Food Compos Anal 2007; 20: 133-137. http://dx.doi.org/10.1016/j.jfca.2006.06.008
[19] Crunkhorn P, Meacock SCR. Mediators of the inflammation induced in the rat paw by carrageenan. $\mathrm{Br} J$ Pharmacol 1971; 42: 392.

http://dx.doi.org/10.1111/j.1476-5381.1971.tb07124.x

[20] Boughton-Smith NK, Deckin AM, Follenfant RL, Whittle BJ, Garland LG. Role of oxygen radicals and arachidonic acid metabolites in the reverse passive arthus reaction and carrageenan paw oedema in the rat. Br J Pharmacol 1993; 110: 896-902.

http://dx.doi.org/10.1111/j.1476-5381.1993.tb13897.x

[21] Di Rosa M. Biological properties of carrageenan. J Pharm Pharmacol 1972; 24: 89.

http://dx.doi.org/10.1111/j.2042-7158.1972.tb08940.x 